\title{
Working Capital Management and Its Impact on the Profitability of Pukar International Co.Ltd.
}

\author{
Puspa Raj Ojha \\ Lecturer \\ Faculty of Management, T.U.
}

\begin{abstract}
This paper aims to report the results of an investigation of the relative importance of working capital management, measured by the Return on Assets (ROA), and its components (Current ratio, average collection period and average payment period) to the profitability of Pukar International Trading. This paper analyzes the effect of working capital Management on firm's profitability in Nepal for the period 2071 to 2072. For this Purpose, financial data of four year is used. Pearson's correlation and Descriptive analysis were used to establish the relationship between working capital management and firm's profitability and components of working capital like Average collection period, Average payment period and Current ratio. The study finds a negative relationship between profitability and average collection period and average payment period, but a positive relationship between profitability and current ratio. Moreover, current ratio and firm size also have significant effects on the firm's profitability. Based on the key findings from this study it had been concluded that the management of a firm could create value for their shareholders by reducing the number of day's accounts collection. Firms could also take long to pay their creditors in as far as they did not worry their relationships with these creditors.

Keywords: Working Capital Management, Profitability, Average Collection Period, Average Payment Period, Current Ratio, Return on Assets
\end{abstract}

\section{Introduction}

Working capital management is a very important component of corporate finance because it has direct impact on liquidity and profitability of the company. Deloof (2003) had used the sample of 1009 large Belgian non-financial firms for a period of 1992-1996, used correlation and regression analysis and found a significant negative relation between gross operating income and the collection period of accounts receivable, average days in inventories and accounts payable of Belgian firms. The shorter the period is required to convert into cash the stronger the liquidity position of the company. Working capital of the company is the relationship between current assets and current liability items. Current assets items can be classified into cash and other asset items which can be converted into cash quickly. The nearer the asset to cash, the lower is the riskiness and the expected return. So it is expected a negative relation between profitability and the length of period over which goods of company are held in non-cash current assets. Current assets of a typical manufacturing firm accounts for over half of its total assets and for distribution company, it account for more. Excessive current assets result in a firm's realizing a substandard return on investment. However firms with few current assets might incur shortages and difficulties in maintaining smooth operations (Horne and Wachowicz, 2000). With regards to current liabilities, the firm was responsible for paying these obligations on timely. Liquidity for the ongoing firm was not reliant on the liquidation value of its assets, but rather on the operating cash flows generated by those assets (Soenen, 1998). 
The ultimate aim of any company is to maximize the profit. But maintaining liquidity of the firm is also an important objective. Increasing profits at the cost of liquidity can bring serious problems to firms so there must be a tradeoff between liquidity and profitability objectives. If profit is not care we won't be able to survive for longer period. On the other hand, if we do not care liquidity, firm may face the problem of insolvency. For this working capital management should be given proper consideration which affect the profitability of the company. Management of short term assets and liabilities deserved the careful analysis since the working capital management had important effect on the firm's profitability as well as its risk (Smith, 1980).

It is necessary to understand the meaning of current assets and current liabilities for learning the meaning of working capital. The current assets had the short life span. These types of assets were engaged in current operation of the business and normally used for short term operations of the firm during the accounting period The financial structure of companies had changed because of the crisis, and companies had been forced to prepare for costly external financing. Financial institutions had improved their conditions, and inflexible companies were struggling to survive (Kargar, \& Blumenthal, 1994). Financial flexibility had become crucial for all companies regardless of their size and company structure. Denis (2011) had explained financial flexibility as the ability to react to unexpected changes in cash flow or investment opportunities with the value-maximizing approach. These were all important to a company adjusting to the new business environment caused by the economic downturn.

The concept of working capital management addresses companies managing of their short term capital and the goal of the management of working capital to promote the satisfying liquidity, profitability and shareholders value. Working capital management was important because of its effects on the firm's profitability and risk, and consequently its value (Smith, 1980). On the one hand, maintaining high inventory levels reduced the cost of possible interruptions in the production process, or of loss of business due to the scarcity of products, reduces supply costs, and protects against price fluctuations, among other advantages (Blinder and Manccini, 1991). On the other, providing on credit favored the firm's sales in various ways. Trade credit could act as an effective price cut (Brennan, Maksimovic and Zechner, 1988; Petersen and Rajan, 1997) incentivizes customers to acquire merchandise at times of low demand (Emery, 1987), allows customers to check that the merchandise they received was as agreed (quantity and quality) and to ensure that the services contracted were carried out (Smith, 1987), and helped firms to strengthen long-term relationships with their customers (Smith and Smith, 1999). However, firms that invest heavily in inventory and trade credit could suffer reduced profitability. Efficient working capital management involved excessive planning and controlling. There must be the balance between current assets and current liabilities in order to eliminate the risk of inability to meet short term obligation on one hand and avoid excessive investment in these assets on the other hand (Eljelly, 2004).

An optimal level of working capital management would be reached by achieving a balance between liquidity and profitability. In fact, if the company adopts a working capital management policy with an excessive level of current assets, the risk of liquidity may be reduced. Working Capital have a greater importance in the profitability and sustainability of any firms. Firms with lower working capital would post a higher return on capital so shareholder will benefit from a higher return. Adequate working capital management will allow a business to pay on time its short term obligations which include raw materials, salaries and other operating expenses. The management of account payables and receivables is an important driver of small firm's profitability. Firms with more efficient working capital management will generate more free cash flows which would result in a higher business valuation. A firm with a good relation with its trade partners and paying its suppliers on time would benefits from favorable financing terms such as discount payments from its suppliers and banking partners. A firm paying its suppliers on time will also benefit from a regular flow of raw materials, ensuring that the production remains uninterrupted and clients receive their goods on time. An efficient working capital management will help a firm to survive through a crisis in case of an unexpectedly large order. Firm with an efficient supply chain will often be able to sell 
Vol. 4, No. 1

their products at a discount versus similar firms with inefficient sourcing.

\section{Objectives}

The major objective is to examine the effect of working capital management on firm's profitability of Pukar international trading company in Nepal. The other objectives are;

- $\quad$ To determine the relationship between average payment period (APP) and profitability of the firm.

- $\quad$ To determine the relationship between average collection period (ACP) and profitability of the firm.

- $\quad$ To examine relationship between current ratio (CR) and profitability of the firm.

Hypothesis

$H_{o l}$ : There is no significant relationship between Average Payment Period (App) and profitability of the firm.

$H_{o 2}:$ There is no significant relationship between Average Collection Period (ACP) and profitability of the firm.

$H_{o 3}:$ There is no significant relationship between Current ratio (CR) and profitability of the firm.

\section{Review of literature}

Many previous researches have indicated the relations between working capital management and profitability of a company in different environments. In literature, Preve and Sarria-Allende, (2010) explained that traditional definition of working capital was current assets minus current liabilities. Working capital management was the management of company's short term assets and short term liabilities explained by Deloof, (2003).It intended to guarantee the sufficient ability of the company to continue its activity and to face operational expenses. More explicitly, the working capital is the investment required from the time lag between the purchase cost of raw materials and the sale of finished products. Its management involves accounts receivable and payable, inventories and cash. The literature for the relevant theoretical and empirical research on working capital components (inventories, accounts payable and receivable) and their effects on corporate profitability is first exposed. Then, existing literature on the influence of the liquidity on corporate profitability was presented. In the sphere of inventory managing, the company aimed to hold a minimal acceptable level of inventory with regard to its costs discussed by Toomey, (2000), Guariglia and Mateut (2006).

Zariyawati, et., al. (2009) also examined the relationship between working capital management and corporate profitability. Cash Conversion Cycle was used as a measured for working capital management and the study was based on panel data for 1,628 company-years for the period 1996-2006 from six different economic sectors listed in Bursa Malaysia. The coefficient results of Pooled OLS regression analysis provided the strong negative significant relationship between Cash Conversion Cycle and corporate profitability. This revealed that reducing cash conversion period results in increased profitability. Thus, company managers should work on shortening cash conversion cycle till optimal level is achieved.

The way in which WC was managed would have the significant impact on the profitability of companies. The significant negative relation between gross operating income and the number of days of accounts receivable, inventories and accounts payables were found. The negative relation between account payables and profitability was consistent with the view that less profitable companies wait longer to pay their bills (Deloof 2003). The chief executives properly recognized the role of efficient use of WC in liquidity and profitability, but in practice they could not achieve it due to suboptimum utilization of WC (Prasad 2001). The Public Sector Enterprises could improve the WCM by reducing their dependence on outside funds (Jain, 1988).

With the aggressive WCM strategy the negative relationship was expected between overall WCM 
(measured by CR), accounts receivable (AR) and profitability, while the positive relationship between accounts payable (AP) and profitability was expected. With the conservative strategy, the positive relationship should exist between $\mathrm{CR}, \mathrm{AR}$ and profitability and the negative relationship between AP and profitability. Empirical evidence of the relationship between CR and its components (INV, AR and AP) and profitability was, however, mixed. For example, the relationship between WCM measured by the CCC and profitability was found to be negative and significant by Raheman et al. (2010), Hayajneh and Yassine (2011) and Karaduman et al. (2011). A positive and significant relationship was reported by Raheman and Nasr (2007), Mathuva (2010), Nobanee and Alhajjar (2009) and Stephen and Elvis (2011), which supported the conservative strategy of WCM. Afza and Nazir (2009) investigated the traditional relationship between working capital management policies and a firm's profitability found the significantly negative relationship between the profitability of firms and working capital investment and financing policies.

Smith and Begemann (1997) concluded that the profitability and liquidity comprised the salient goals of working capital management. The problem was aroused because the maximization of the firm's returns could seriously threaten its liquidity, and the pursuit of liquidity had a tendency to dilute returns. The statistical test results showed that a traditional working capital leverage ratio, current liabilities divided by funds flow, displayed the greatest associations with return on investment. Well known liquidity concepts such as the current and quick ratios registered insignificant associations whilst only one of the newer working capital concepts, the comprehensive liquidity index, indicated significant associations with return on investment.

\section{Conceptual Framework}

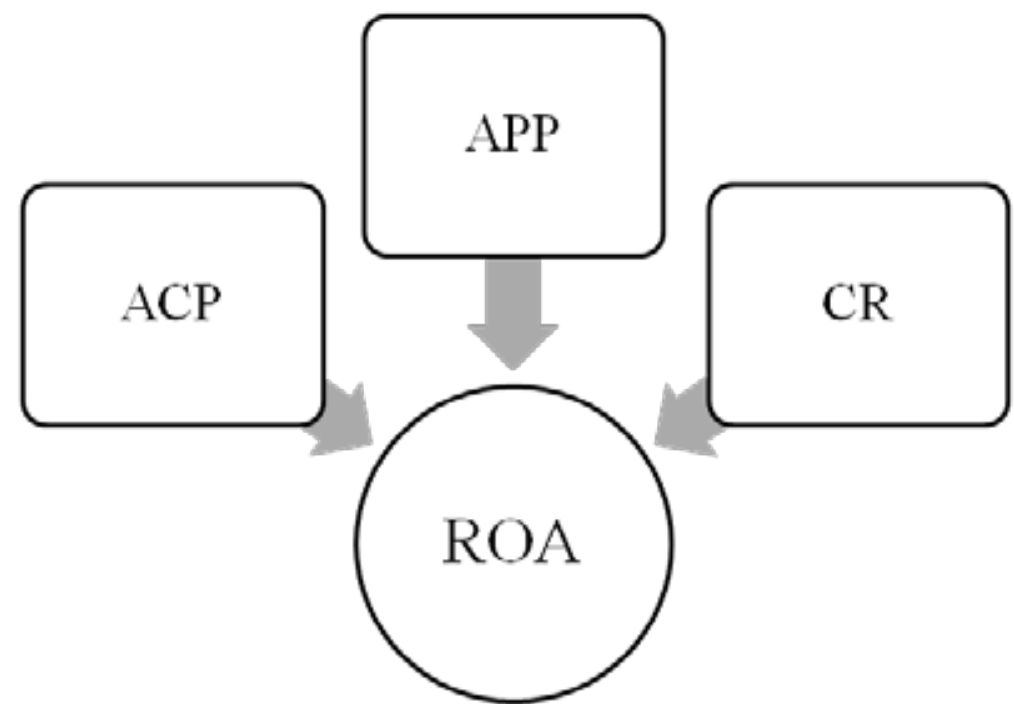

Figure 1: Conceptual framework

ACP, APP and CR are the independent variables which affect the dependent variable ROA which shows the profitability of the firm. ACP is the average number of days between the dates that a credit is made to the date that money is received from customer. APP is a period in which business or firm typically takes in paying off its purchase that have been made by credit. CR is a liquidity ratio that measures a company's ability to pay short term and long term obligations. The current ratio is also known as the working capital ratio.

\section{Research Methodology}

In view of the objective of the study listed above a descriptive and analytical research design have been adopted. A quantitative research design is used to examine the relationship between variables by using 
Vol. 4, No. 1

numbers and statistics to explain and analyze its findings. Researcher has followed scientific approach to design the research methodology for investigation. For this study secondary data is used as a source of information for the period of four year from 2071 to 2074 B.S. The tools used for the study is SPSS program. The researcher picks up the techniques to suit their requirement and also basis to data available to them. The descriptive analysis and correlation analysis technique have been used for the analysis. This study was concerned with the relationship of working capital management on profitability. It aimed at identifying the relationship of working capital components such as Average collection period, average payment period and current ratio on profitability. These variables have been selected as independent variable to analyze relationship between WCM and profitability. For this, ROA is chosen as the dependent variable. Measurement of the variables can be calculated by the following formula

ROA $=$ Net Income/Average Total assets

APP $=$ Accounts payable/Cost of sales * 365

ACP $=$ Accounts Receivable/Net sales * 365

$C R=$ Current assets $/$ Current Liabilities

\section{Data presentation and analysis}

The results are presented from descriptive and quantitative data analysis using SPSS. Descriptive analysis is presented first followed by correlation analysis. It shows the mean and standard deviation of different variables in this study. It also gives minimum and maximum values of the variables.

Table 1 Descriptive Statistics

\begin{tabular}{|c|c|c|c|c|c|}
\hline & $\mathrm{N}$ & Minimum & Maximum & Mean & Std. Deviation \\
\hline APP & 4 & 7.06 & 56.51 & 32.7675 & 20.98338 \\
\hline ACP & 4 & 7.27 & 141.05 & 65.1700 & 55.60261 \\
\hline CR & 4 & 4.74 & 20.59 & 11.7100 & 8.00658 \\
\hline ROA & 4 & 2.44 & 4.10 & 0.32700 & 0.08622 \\
\hline & & & & & \\
\hline
\end{tabular}

Table 1 shows the summary of the variables used in the study for the annual financial data of four year. The mean value of return on assets is $32.7 \%$ with standard deviation of $8.62 \%$. The average payment period is 32.7675 days with a standard deviation of 20.9833 days. Average collection period shown by the study is 65.17 days with standard deviation of 55.60 days. The firm in the study has a current ratio of 11.71 .

\section{Correlation analysis}

Table 2 shows the correlation among the observed variables in the study. A correlation coefficient is a statistical measure of the degree to which changes to the value of one variable predict change to the value of another variable. A positive correlation indicates the extent to which those variables increase or decrease in parallel and a negative correlation indicates the extent to which one variable increases as the other decreases. 
NCC JOURNAL - 2019

Table 2 Correlations

\begin{tabular}{|c|c|c|c|c|c|}
\hline & & APP & $\mathrm{ACP}$ & CR & ROA \\
\hline \multirow{3}{*}{ APP } & Pearson Correlation & 1 & & & \\
\hline & Sig. (2-tailed) & & & & \\
\hline & $\mathrm{N}$ & 4 & & & \\
\hline \multirow{3}{*}{$\mathrm{ACP}$} & Pearson Correlation & 0.539 & 1 & & \\
\hline & Sig. (2-tailed) & 0.000 & & & \\
\hline & $\mathrm{N}$ & 4 & 4 & & \\
\hline \multirow{3}{*}{ CR } & Pearson Correlation & 0.938 & 0.732 & 1 & \\
\hline & Sig. (2-tailed) & 0.042 & 0.000 & & \\
\hline & $\mathrm{N}$ & 4 & 4 & 4 & \\
\hline \multirow{3}{*}{ ROA } & Pearson Correlation & 0.131 & 0.669 & 0.162 & 1 \\
\hline & Sig. (2-tailed) & 0.000 & 0.000 & 0.000 & \\
\hline & $\mathrm{N}$ & 4 & 4 & 4 & 4 \\
\hline
\end{tabular}

*Correlation is significant at the 0.05 level (2-tailed)

The results of the Pearson correlation coefficients are presented in Table 2 for all variables included, to assess the association between the ROA and its components CR, ACP and APP. Based on the Correlation coefficient it is evident that ACP has a more significant relationship to Profitability measured by ROA. Table 2 shows that correlation between ROA is low correlation with APP and moderate correlation with ACP. The components of working capital management like ACP, APP, CR are taken in the study and observed the relationship between them.

$H_{I}$ : There is significant relationship between Average Payment Period (App) and profitability of the firm $(r=0.000<0.05)$.

$\mathrm{H}_{2}$ : There is significant relationship between Average Collection Period (ACP) and profitability of the firm $(r=0.000<0.05)$.

$\mathrm{H}_{3}$ : There is significant relationship between Current ratio (CR) and profitability of the firm $(r=0.000<0.05)$.

\section{Conclusion}

The objective of the study was to investigate the relative importance of WCM, measured by return on assets (ROA) and its components (CR, ACP, APP) to the profitability Pukar international trading .In descriptive analysis, the mean of APP is 32.76 days, mean of ACP is 65.10 days. Similarly mean of CR is 11.71 and ROA is $32.70 \%$.From correlation analysis, relation between ROA and APP is low correlation with 0.131 , moderate correlation between ROA and ACP with 0.669 and finally low correlation between ROA and CR with the value 0.162 .Hence from the above correlation analysis table we found that there is significant relationship between APP and profitability of the firm. significant relationship between ACP and profitability of the firm was observed. Finally there is significant relationship between CR and profitability of the firm was observed. 


\section{References}

Atrill, P. (2006). Financial management for decision makers. London: Pearson Education Ltd.

Blinder, A. S. \& Maccini, L. J. (1991). The resurgence of inventory research: What have we learned? Journal of Economic Survey, 5, 291-328.

Brennan M., Maksimovic, V. \& Zechner, V. (1988). Vendor financing. Journal of Finance, 43, 1127-1141.

Brian, B. (1979). Working Capital Policy and Liquidity in the Small Business. Journal of Small Business Management, 17(3), 120-185.

Deloof, M. (2003). Does working capital management affect profitability of Belgian firms? Journal of Business Finance \& Accounting, 30 (3/4), 573-587.

Eljelly, A.M.A. (2004). Liquidity-profitability tradeoff: An empirical investigation in an emerging market. International Journal of Commerce \& Management, 14(2), 48-61.

Emery, G. W. (1987). An optimal financial response to variable demand. Journal of Financial and Quantitative Analysis, 22, 209-225.

Field, A. (2005). Discovering Statistics Using SPSS for Windows. CA: Sage Publications, Thousand Oaks.

García-Teruel, P.J. \& Martínez-Solano, P. (2007). Effects of working capital management on SME profitability. International Journal of Managerial Finance, 2(3), 164-177.

Hill, M.D., Kelly, G.W. \& Highfield, M.J. (2010). Net operating working capital behavior: A first look. Financial Management, summer 2010, 783-805.

Horne, J. \& Wachowitz, J.M. (2000). Fundamentals of Financial Management. New Jersey: Prentice-Hall International Inc.

Kargar, J. \& Blumenthal, R. A. (1994). Leverage impact of working capital in small businesses. TMA Journal, 14(6), 46-53.

Kayanula, D. \& Quartey. (2000). Paper on the Policy Environment for Prompting Small and Medium-Sized Enterprise in Ghana and Malawi University of Manchester: Crawford House.

Ng, C. K., Smith, J. K. and Smith, R. L. (1999). Evidence on the determinants of credit terms used in interfirm trade. Journal of Finance, 54, 1109-1129.

Petersen M. A. \& Rajan, R. G. (1997). Trade credit: Theories and evidence. Review of Financial Studies, 10, 661-691.

Ricci, C. \& Vito, N. D. (2000). International Working Capital Practices in the UK. European Financial Management, 1(6), 69-84.

Shin, H. H. \& Soenen,L. (1998). Efficiency of working capital and corporate profitability. Financial Practice and Education, 8, 37-45.

Smith K. (1980). Profitability versus liquidity tradeoffs in working capital management. In Readings on the Management of Working Capital. Ed. K. V. Smith. St. Paul, West Publishing Company, 549-562.

Smith, J. K. (1987). Trade credit and informational asymmetry. Journal of finance, 42, 863-872.

Wilner, B. (2000). The exploitation of relationships in financial distress - the case of trade Credit. The Journal of Finance, 55(1), 153-178. 